\title{
Первые впечатления о психологических проблемах Беслана
}

Своеобразие психологических проблем первичных и вторичных жертв теракта в Беслане состоит в деструкции межличностных отношений в республике, в том числе национальных, вероисповедальных, семейных и педагогических, в беспрецедентно резком падении авторитета данных социальных институтов, в выраженном национальном колорите происходящих перемен.

Причины этих явлений лежат в явной недооценке названных обстоятельств, неординарности происшедшей беды, сложившейся социальной ситуации в Беслане и Северной Осетии в целом представителями всех ветвей власти, органов правопорядка, системы образования и здравоохранения до, во время и после террористического акта; в имеющих место упущениях в ведении следствия, освещении его предварительных результатов, в распределении материальной помощи потерпевшим; в явном недоучете ценностей морального плана, национальных, вероисповедальных, семейных традиций народа с богатейшей славной историей; в бессистемном, случайном, непоследовательном характере профессиональной психологической помощи населению. 